\title{
FAILURE, THE NEXT GENERATION: \\ WHY RIGOROUS STANDARDS ARE \\ NOT SUFFICIENT TO IMPROVE SCIENCE LEARNING
}

\author{
MARY ANTONY BAIR \& DAVID EDWARD BAIR \\ Grand Valley State University, Special Education, Foundations and Technology
}

\begin{abstract}
Although many states in the United States are adopting policies that require all students to complete college-preparatory science classes to graduate from high school, such policies have not always led to improved student outcomes. There is much speculation about the cause of the dismal results, but there is scant research on the processes by which the policies are being implemented at the school level, especially in schools that enroll large numbers of historically non-college-bound students. To address this gap in the literature, we conducted a four-year ethnographic case study of policy implementation at one racially and socioeconomically diverse high school in Michigan. Guided by the structuration theory of Anthony Giddens (1984), we gathered and analyzed information from interviews with administrators and science teachers, observations of science classes, and relevant curriculum and policy documents. Our findings reveal the processes and rationales by which a state policy mandating three years of college-preparatory science for all students was implemented at the school. Four years after the policy was implemented, there was little improvement in science outcomes. The main reason for this, we found, was the lack of correspondence between the state policy and local policies developed in response to that state policy.
\end{abstract}

Keywords: Policy implementation; Science standards; High school science

Mary Antony Bair \& David Edward Bair (2014). Failure, The Next Generation: Why Rigorous Standards are not Sufficient to Improve Science Learning. International Journal of Education Policy \& Leadership 9(5). Retrieved from www.ijepl.org.

\section{Introduction}

Concern about the mediocre performance of American students in comparison to their international peers has led to a renewed focus on science education in the United States. Results from the 2011 Trends in International Math and Science Study (TIMSS) show that the average U.S. score in eighthgrade science ranked $13^{\text {th }}$ out of 56 countries and education systems. Only 10 percent of U.S. eighth graders reached the Advanced international benchmark (Buckley, 2012). This trend has long-term consequences for current students. It is anticipated that the majority of jobs in the $21^{\text {st }}$ century will require three or four years of high school science. Furthermore, there is evidence that students who take more advanced mathe- matics and science courses have higher earnings as adults (Rose \& Betts, 2004). Therefore, to keep options open and to maximize their future opportunities, students are being required to follow a rigorous curriculum of math and science in high school (Nextgenscience.org, 2013a).

Improving science education has become a national priority. Millions of federal dollars, through Race to the Top Round 3, have been offered to states that have plans to improve science, technology, engineering, and math (STEM) education for all students. Furthermore, in public-private partnerships, companies such as the Intel Corporation have pledged hundreds of millions of dollars to improve STEM college and career readiness for all students (Montgomery, Allensworth, \& Correa, 2010). While new science standards, titled the Next Generation
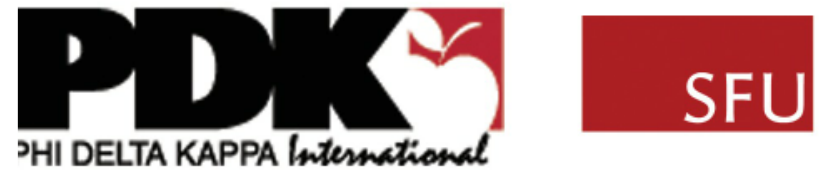

SIMON FRASER UNIVERSITY THINKING OF THE WORLD

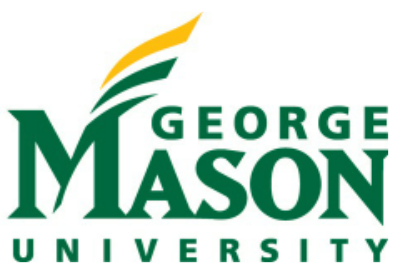


Science Standards (NGSS), were only recently released in April 2013 (Nextgenscience.org, 2013b), rigorous standards are already the norm, with 23 states requiring a college-preparatory curriculum for all students (Achieve, Inc., 2012).

Michigan is one such state. In 2006, it adopted legislation mandating a new set of graduation requirements called the Michigan Merit Curriculum, which required all high school students to complete three credits of college-preparatory science to graduate. The subjects required were biology, chemistry or physics, and a third credit of science (Michigan Department of Education, 2012a). With the adoption of the Michigan Merit Curriculum, Michigan is now one of 20 states that require three credits of science for all students (Achieve, Inc., 2008); most states require only two. Prior to the adoption of this policy, high school graduation requirements were decided at the local level; the state of Michigan required only half a credit of civics. In 2005, 46 percent of Michigan districts required biology, 10 percent required chemistry, and only 6 percent required physics for graduation from high school (Dynarski, Frank, Jacob, \& Schneider, 2012).

There is little disagreement about the importance of improving the quality of science education; there are, however, mixed findings regarding the effectiveness of policies that mandate college-preparatory curricula for all students (Allensworth, Nomi, Montgomery, \& Lee, 2009). Some studies have found positive academic outcomes for students who attended schools where most students were required to take college-preparatory courses. For example, following the increase in graduation requirements, lowachieving students were found to take more academic science courses than they would have otherwise (Dynarski et al., 2012; Montgomery et al., 2010). Dynarski, Frank, Jacob, and Schneider (2012) also found a small increase in the science performance of high-achieving students. Researchers report that providing accelerated curricula to low-achieving students did not lead to an increased dropout rate (Teitelbaum, 2003).

On the other hand, there have been some reports of negative outcomes related to requiring rigorous coursework for all, especially for historically lowachieving students. Montgomery, Allensworth, and Correa (2010) found little evidence of improved science learning or college outcomes following an increase in science course requirements in Chicago public schools. Although the policy did result in more students taking and passing collegepreparatory science classes, approximately 80 percent of students earned a grade of $\mathrm{C}$ or lower. The researchers argue that the policy did not help students learn more science and, because the collegegoing rates of those earning B and above declined, that the policy may have hurt their college prospects. They also found an initial decrease in graduation rates following the adoption of this new policy. Dynarski et al. (2012) also report little or negative effect on the performance of low-achieving students and a decrease in graduation rates following the adoption of mandatory college-preparatory curricula.

Researchers hypothesize that one reason for the negative outcomes might be the manner in which the policies are implemented at the local level. For example, when confronted with increased academic requirements, some schools may simply re-label existing courses rather than redesign more rigorous courses, leading to a dilution of course content (Dynarski et al., 2012; Loveless, 2008). Spillane (2004) describes how the district personnel's misinterpretation of policy led to practices that were contrary to the original intent; they reduced complex notions of knowledge construction to simple handson activities.

Montgomery, Allensworth, and Correa (2010) found that Chicago public schools offered environmental science as one of the three collegepreparatory science requirements. Students who took three years of science may have taken environmental science, biology, and either physics or chemistry. However, because both chemistry and physics are typically required for admission to select colleges, the lack of one of these two subjects might have negatively affected their admission to these colleges.

Findings such as these have led to calls for research that examines not only the outcomes of policies requiring rigorous science for all students, but also the process by which such policies are implemented in the school and classroom (Achieve, Inc., 2011; Allensworth, Nomi, Montgomery, \& Lee, 2009; Dynarski et al., 2012; Montgomery et al., 2010; Roth, Tobin, \& Ritchie, 2007; Rubin, 2008).

Currently, we know little about how schools are responding to policies mandating collegepreparatory curricula for all students in terms of organizing classrooms (Nomi, 2012). Although Byrd and Langer (2010) did survey administrators to understand how they were responding to the Michigan Merit Curriculum, most of the responses came from administrators of districts that had few students living in poverty, few minority students, and many schools that were likely to make adequate yearly progress (AYP) in meeting the requirements of No Child Left Behind (NCLB). Thus, little is known 
about the manner in which schools that serve traditionally non-college-bound students are coping with the rigorous academic requirements in science.

We conducted this study in an attempt to respond to this gap in our knowledge by asking the following research questions:

- How did the staff at one diverse high school respond to a state-mandated graduation policy requiring a college-preparatory science curriculum for all high school students?

- What were the changes adopted by the school?

- What was the rationale behind these changes?

- What was the effect of these changes on the teaching and learning of science?

The findings of this study contribute to the science education literature by revealing how, in responding to state mandates, well-intentioned school staff adopted policies related to scheduling and curriculum that conflicted with the goal of the state policy and inadvertently undermined some students' opportunities to learn science. If standards-based reforms such as the NGSS truly seek to prepare more students for STEM careers, reformers need to pay attention to local policy implementation, not just policy development.

\section{Theoretical Framework}

This study was guided by the structuration theory of Anthony Giddens (1984), which postulates a recursive relationship between social structure and human agency. Agency, according to Giddens, refers to the capability of individuals to act. Social structure encompasses two main concepts: rules and resources. Rules of social life can be thought of as generalizable procedures applied in the enactment of social practice. According to Giddens, rules structure or give shape to the practices that they help to organize. Resources account for the necessary amenities that make the exercise of power possible. When agents draw upon rules and mobilize resources in social interactions, they simultaneously reproduce the structure of social practice. Within this theoretical framework, policy is seen as social practice that agents interpret and adopt within contextual and structural constraints (Smit, 2005; Spillane, 2004).

\section{Method}

The research reported in this article is drawn from a broader ethnographic case study on policy imple- mentation (Bair \& Bair, 2011). The study was guided by Povall's (2006) definition of policy ethnography: "[It] is a methodological approach employed to look at the details of policy implementation by studying a single case" (p. 5). Our approach was to study a single school, and to obtain as holistic a picture as possible of the knowledge people had of the Michigan Merit Curriculum, how they made sense of the policy, factors that shaped their decisions, and how the daily, taken-for-granted routines of schooling were a manifestation of their understandings. In this article, we focus specifically on findings related to the implementation of state-mandated science standards.

We spent four years (2006-2010) at Reform High School (RHS, a pseudonym), a large, comprehensive high school in Michigan that is located on the fringe of a city. We selected this school because we wanted to examine the process of policy implementation in a school that was diverse in terms of ethnicity and socioeconomic status and historically had large numbers of students enrolled in noncollege preparatory classes. We also sought a school that had a good reputation and did not have many of the confounding problems typically associated with urban schools.

During the first year, we visited the school at least once a week. These regular visits enabled us to develop relationships with the participants, and the time in between visits gave us the time to read, reflect, and write about our visits. In fall 2007, we selected the recurrent time mode of sampling (Troman, Jeffrey, \& Beach, 2006), which guided us in making observations and conducting interviews during the beginning, middle, and end of each trimester. This enabled us to study the complete cycle of a school year and to compare different phases of the cycle. If there was something of particular interest occurring in the school, such as special assemblies or presentations to students, we observed these. By the end of winter 2010, when we felt that no new information was being gained from additional visits, we decided to conclude the study.

\section{Data Sources}

Utilizing the process of triangulation (Patton, 1990), we gathered data from multiple sources: interviews with school staff, observations of science classrooms, and analyses of various documents related to science curricula and policy. We conducted annual interviews with 12 high school science teachers to understand their responses to the Michigan Merit 
Curriculum policy. We asked them about professional development they had received to adjust to the new state policy; their perceptions of the effect of the policy on science curricula, instruction, and assessments; and any concerns they had with the policy or its implementation. We also conducted numerous brief, unscheduled interviews, catching teachers between classes to clarify what we witnessed. Each year we also conducted semi-structured interviews with five administrators (one assistant superintendent, two principals, and two assistant principals) and two school counselors (the head counselor and a freshman counselor) to understand how they were interpreting and responding to the new graduation standards. Administrators were asked about school policies and the rationales behind changes that were implemented at the school.

Although the interviews were our primary source of data, each year we also observed 12 science classrooms. Our role in the classroom was that of nonparticipant observers. We noted the science content that was covered, the instructional strategies that were used, and student participation in classroom activities. In addition, we observed other relevant school events such as school assemblies, grade-level presentations by the school counselors, staff meetings, and professional development presentations.

Our third source of data was artifacts: the text of the Michigan Merit Curriculum, school curriculum handbooks, textbooks, school schedules, school policies, classroom handouts, school newsletters, and community newspapers. We also obtained demographic information and student achievement data. Administrators gave us some of these documents, and we obtained others from the websites of both the Michigan Department of Education and RHS.

To enhance the credibility of our study (Guba \& Lincoln, 1989), we spent four years in the school. This allowed us to build rapport with the participants and observe changes over time. We also conducted member checks (Glesne \& Peshkin, 1992) to ensure that we were honest in our representation of the participants and events.

\section{Data Analysis}

Data analysis was an ongoing process in which data collection and analysis overlapped. Demographic data, pass/fail rates, and achievement test scores were analyzed using descriptive statistics. Qualitative data-such as classroom observations, interview transcripts, and documents (e.g., curriculum guides, lesson plans, and textbooks)-were subject to con- tent analysis (Strauss \& Corbin, 1990). Initial data analysis occurred while we were still in the field. As we transcribed interviews or typed the field notes, we made note of patterns and contradictions that were emerging. We formulated hunches and tentative hypotheses, which we tested through further observations, interviews, or document analyses. Whenever possible, we tried to reduce data into tables and charts, constantly searching for themes and patterns.

We utilized both structural and interpretive analysis. During structural analysis, we counted and listed courses that were eliminated, new courses that were added, numbers of sections of different science classes, and teachers assigned to teach the courses. We used interpretive analysis to analyze the interviews and field notes of classroom observations. First, we read the narrative and generated codes to summarize data (open coding); some of the codes that emerged were detracking, trimesters, pace, content, strategies, requirements, electives, and power standards. During the next stage of axial coding, we grouped like codes together to generate categories such as school organization, classroom organization, curriculum requirements, instructional strategies, and assessment constraints. We drew tables and charts to help find relationships between categories and concepts. We wrote memos to describe relationships between different categories, generate possible hypotheses, and explore categories that seemed to be significant.

\section{Findings}

\section{Context}

In 2006, when we began the study, the school enrolled more than 2,000 students. Of these, approximately 57 percent were White, 28 percent AfricanAmerican, 7 percent Hispanic, and 7 percent Asian; more than 40 percent of the students were eligible for free or reduced lunch. By 2010, the overall enrollment had dropped to approximately 1,884 students and the demographic composition had changed to approximately 50 percent White, 31 percent African-American, 8 percent Hispanic, 8 percent Asian, and 4 percent two or more races; more than 44 percent of the students were eligible for free or reduced lunch.

Requiring college-preparatory science courses for all students was a dramatic shift for Reform High School. In 2006, when the school began implementing the state policy requiring three years of college- 
preparatory science for all students, approximately a quarter of the students were tracked into non-college preparatory high school courses. African-American and Hispanic students were overrepresented in the lower tracks and virtually absent from collegepreparatory math and science classes.

\section{Structural Changes}

The state policy mandating college-preparatory science for all students was supported by the teachers of the science department at RHS, who were critical of the explicit tracking that had been prevalent in the school. "Kids cannot rise to low expectations," explained one teacher. Committed to the notion of rigorous science for all students, the faculty of the science department eliminated all lower-track classes such as Science Concepts, which had previously been taken by almost 65 percent of the students. This left a single set of courses for all students. All incoming freshmen were enrolled in ninth-grade biology. Students in $10^{\text {th }}$ and $11^{\text {th }}$ grade were to take chemistry and physics, in either order. Teachers were confident that requiring more rigorous standard science courses would raise achievement.

The rigorous academic requirements of the Michigan Merit Curriculum spelled out not only the 16 credits a student needed for graduation (each credit being a full year course), but also the specific courses and the specific high school content expectations to be met. Such specific requirements dictated almost 75 percent of the courses that students needed to take during their high school careers, leaving room for only one or two elective courses per year. Teachers feared that this increase in academic requirements and the corresponding decrease in time available for electives would negatively influence school attendance. Elective courses like art and music were thought to be vital for many students. "Students who struggle academically need those electives. That is the only reason they come to school," explained an administrator.

To make room for electives, the entire school changed from a semester schedule to trimesters. Full-year course sequences that formerly took two semesters, or 36 weeks, were compressed into two trimesters, or 24 weeks. The trimester schedule allowed students to take 15 courses in a year (instead of 12 under the semester schedule), thus providing more opportunities for students to take electives beyond the required courses. (For a detailed discussion on the effect of trimesters, see Bair \& Bair, 2010.)
In addition, administrators were concerned that many students would fail the academically challenging requirements. They were concerned that failing even a part of the course could prevent students from graduating on time. "Under semesters, there is no wiggle room," explained an assistant principal. All college-preparatory science courses were twosemester courses: for example, ninth graders would typically take biology A in the first term and biology $\mathrm{B}$ in the second. Under the semester schedule, a student who failed biology $\mathrm{A}$ in the first term and retook it during the second would fall a semester behind in completing the science requirements. On the other hand, under the trimester system a student who failed a course in the first trimester could retake it during the second trimester, complete the course sequence third trimester, and still be on schedule to graduate on time. This possibility of helping students graduate on time further solidified the administrators' decision to adopt the trimester schedule.

\section{Challenges for Science Teachers}

Although the administrators made decisions about structural changes at the school level, they left it up to the teachers to figure out how to implement the new standards at the classroom level. "We were just handed the standards," said a chemistry teacher. There were 163 content standards to be covered in biology, and 152 in chemistry. Not only were the standards numerous and rigorous, but teachers found them to be confusing. One teacher told us, "There are a massive number of standards, many of which are not clear what they mean." Another reiterated this concern: "A topic or concept may be listed in the standards; it is not clear how far or how much to go into it." A chemistry teacher who had just moved from another state felt that "Michigan standards are a collection of disjointed facts ... a collection of concepts stated as standards, without always a clear connection between concepts."

The second challenge was translating the standards into classroom instruction. When asked how they were aligning instruction to meet these standards, several teachers told us that they were "flying by the seat of [their] pants." One teacher pointed out the lack of a clear focus on pedagogy in the state policy. The state, according to her, had mandated the content students were to know, but had left it to local discretion to figure out how to translate the standards into student achievement. Lacking any clear 
directions, the goal of classroom instruction became to try to cover all the mandated state standards before the term ended.

The third problem was a lack of time. Exacerbating the challenge of having to address the long list of high school content expectations was the new trimester schedule. Content had to be covered in a 12week trimester instead of an 18-week semester. According to the administrators, the total instructional time was the same under both schedules. Although technically this might have been accurate, in reality the administrators adopted some other policies that detracted from the time available for science instruction. For example, believing in the importance of building relationships with students, the school adopted a positive behavior support system called Capturing Kids' Hearts. As part of this program, the first 15 minutes of each class were used for openended discussions that facilitated an emotional connection between the teacher and students. It was only after this relationship-building time that teachers could begin addressing the curriculum. Teachers agreed that it was crucial to build relationships with students, but they felt that during the rest of the period it was "pedal to the metal."

In addition to a lack of time in each class period, according to a biology teacher, the shortened 12week term meant fewer evenings and weekends for students to assimilate information, develop inquiry skills, and complete homework assignments. As he put it, "Trimesters do not give students enough soak time ... time to process, think, and reprocess." The general consensus was, "If we had more time, all could do significantly better."

Not only did teachers face the daunting task of teaching the increased standards in a shorter term, they were also confronted with a large number of students who were unprepared for collegepreparatory courses. A chemistry teacher expressed confidence that 75 percent of the students would not take chemistry if it was not required. A biology teacher pointed out the weak reading skills that led some students to struggle in biology class (considered a reading-intensive course). Likewise, a physics teacher pointed out that many students did not possess prerequisite math skills necessary to master certain topics in physics and chemistry.

\section{Unintended Consequences}

\section{Effect on science instruction}

Following the implementation of the Michigan Merit Curriculum, a third of the freshmen at RHS failed biology. For two years in a row, the school failed to demonstrate adequate yearly progress (AYP) as required under federal NCLB legislation. Several changes were quickly instituted by the district-level administrators. The existing principal, who was not perceived as an instructional leader, was replaced by a new principal who was charged with raising student achievement. A school improvement team was created to develop strategies to address the needs of "struggling students." New attendance and pass policies were established by the team. For example, the percentage needed to pass a course was changed from 77 percent to 59 percent.

The school improvement team recommended the adoption of power standards, or "standards worth teaching." During the summer of 2008, teachers gathered at the intermediate school district and developed power standards- the specific sub-set of the standards that would be assessed on the state tests. When we inquired how the teachers had determined which standards were worthwhile, we were told that a team had examined the standardized assessments and identified the standards that were most likely to appear on the Michigan Merit Exam. Teachers at RHS were told to focus on these standards and teach what was being assessed. For example, a biology teacher explained that, through the process of "massaging the curriculum to fit the standards," teachers taught what was assessed and just skipped the rest. Teachers were told to focus on the needs of the struggling students because it was the low scores of these students that had resulted in the school's failure to demonstrate adequate yearly progress.

Teachers were not happy with the consequences of these changes on classroom instruction. They felt that the focus on power standards and assessments contradicted the inquiry-based teaching methods that were the spirit of science education reform. However, the teachers' misgivings fell on deaf ears. In the words of an unsympathetic administrator:

Teachers are putting too much pressure on themselves. ... They need to try and figure out the power standards, the main standards that the state is saying we must cover. Teachers are trying to cover everything instead of using them as a guide. Teachers 
start at chapter one and go till chapter ten. "This is what I have always done" is what they think. Instead they should think, "This is what is on the ACT"-or they could pretest and figure out where students are and then teach accordingly.

So, gradually, teachers gave up the inquiry-based instruction for content coverage and test preparation. "[Now] the whole curriculum is aligned to the test," complained one teacher.

"Labs get cut out because they are a timeconsuming way to learn and there is not that time in trimesters," said a biology teacher, who showed us how many dissections she had eliminated from the curriculum. A chemistry teacher was appalled at the cuts she was asked to make: "I am teaching chemistry without titrations." According to teachers, there was no time for movies or discussions, which students used to enjoy. Several teachers pointed to the lack of time for valuable instructional practices, such as review and practice, investigations, and application of concepts. One teacher put it this way: "[There is] less time for problem solving, critical thinking, graph reading, developing students' skill in how to think like a scientist, helping students learn how to set up experiments. ..." Instead, each week, teachers in the biology, chemistry, and physics classes were told to give "ACT-like assessments" to prepare students for the standardized tests upon which the school's status hinged.

\section{Effect on detracking process}

The Michigan Merit Curriculum was intended to "provide all students with the same rigorous curriculum and credit content" (Michigan Department of Education, 2012a). Even though the teachers embraced the concept of detracking and having rigorous requirements for all students, they were unprepared for dealing with the heterogeneous classes in which students had a wide range of achievement. The wide range in ability was particularly noticeable in second- and third-trimester classes, which enrolled students who were repeating the class because they had already failed it once or twice along with others who were taking it for the first time. One teacher described these classes as having a bimodal distribution, "like a dromedary." One group of students was clustered around A and B grades, and another group around $\mathrm{D}$ and failing grades. Teachers felt that this reflected the variability in prior preparation and work habits. Most students who failed simply were not turning in their work. "If they turn their work in they will at least pass with a D," stated a teacher.

Ultimately, the students who were repeating the course tended to dominate the classes in a negative manner. Teachers felt this was unfair to the students who were taking a class for the first time. Following numerous complaints and requests, students who had failed a class were grouped together into sections called "repeaters." These sections were reputed to be the hardest to teach, yet our observations revealed that the newest, least-experienced teachers were assigned to them. In addition, students who failed repeatedly were required to take new electives created for this growing body of struggling students. This included a course to specifically prepare for the junior year state-mandated standardized test ("ACT Prep") and credit recovery courses, including online instructional programs such as E-2020, in which the curriculum was fragmented into units and students passed the course one unit at a time.

Meanwhile, other students attended the regular sections of physics, chemistry, and biology. Our interviews revealed that teachers felt the curriculum in these regular courses had also been simplified. One science teacher told us that what was now taught as chemistry "is really dumbed-down chemistry." Likewise, there was a lower-level physics called "active physics." What had previously been the only chemistry course was now called "accelerated chemistry." The accelerated sections of chemistry and physics we observed moved at a faster pace than the regular chemistry sections, covered additional standards, and prepared students for advanced placement classes. However, according to a science teacher, even the curricula in these accelerated classes were a diluted version of what is typically considered college-preparatory chemistry. "Accelerated chemistry is really not advanced chemistry. ... It is still a diluted version of the traditional college-preparatory chemistry. We go at a faster pace than the regular chemistry, that is all."

"These courses used to be for kids who want to go to college. Now a D is considered passing!" explained another teacher.

Thus, despite the best intention to de-track science classes and offer college-preparatory curricula for all students, in reality a re-tracking of students occurred. Three tracks emerged in high school science: general, accelerated, and advanced placement. One teacher told 
us: "We're segregating kids. We wanted to get rid of tracking, but we have created a track of those who haven't passed. ... We are siphoning off the good kids and a new track is emerging with failures."

Furthermore, some students who repeatedly had discipline problems were expelled, transferred to the alternative school, or dropped out. Counselors suggested to some frustrated students that the alternative school might be a better placement for them. The number of students at the alternative school was "exploding," according to one teacher. When we checked, we found that in 2005 the enrollment had been 182 students; by 2009, it had grown to 250 students.

Student performance in science at RHS, as measured by Michigan Merit Exam (MME) scores, declined between 2007 and 2011 (Michigan Department of Education, 2012b). The overall percentage of students classified as proficient in science on the Michigan Merit Exam (MME) dropped from 55 percent in 2007 to 50 percent in 2011. However, during this same period there was an increase in the percentage of non-disadvantaged students ( $9 \%$ to $12 \%$ ) who scored at the advanced level on the MME.

Thus, although the school adopted many changes to help the struggling students, in reality the changes helped the successful students. Students who passed courses at the first attempt had time for electives. Some took three terms of academic courses; others were able to either test out of courses, take more advanced placement courses, or even dual-enroll at a university. But the gains made by a small portion of academically talented students did not make up for the adverse effects on a larger proportion of the student population that experienced academic challenges.

\section{Effect on teacher expectations}

Meanwhile at RHS, teachers began to wonder if the rigorous requirements were appropriate for all students. One teacher believed that "some students really need to learn a trade. ... This new curriculum does not acknowledge or address these learners." Another teacher stated: "I suppose they can learn it, but I ask, what for? They are not going to college. The governor will realize that we need plumbers and electricians. This will change." According to a biology teacher, policy makers, who were "self-starters and high achievers," did not understand that many students did not share that level of persistence or initiative. "They have set the bar too high. Not all students have the skills to meet the new standards."

\section{Discussion}

The findings of this case study reveal that requiring science for all students did not lead to improved student outcomes at RHS, especially for students who have been historically underrepresented in STEM fields. We found that teachers and administrators had the best of intentions: they wanted to help all students, especially disadvantaged students, find academic success. But good intentions were not enough.

Detracking is a complex process and teaching heterogeneous classes is a refined, specialized skill. Researchers have noted the difficulty in implementing standards-based instructional practices in diverse urban school systems. The challenges include lack of resources, high levels of poverty, low student achievement, below-grade-level English proficiency, high student mobility, attendance problems, and difficulty recruiting and retaining highly qualified teachers (Geier et al., 2007). Yet the school staff received no guidance on how to address the learning needs of students who came with varied levels of preparedness.

We encountered teachers willing and able to determine how to teach the new and revised expectations to their students, but they did not have the time or support to figure out how to make the dramatic and immediate shift that was expected of them. Similar findings have been noted by Penuel, Fishman, Gallagher, Korbak, and Lopez-Prado (2009), who found that lack of time to plan for curriculum implementation was a significant problem for teachers in their study. Although policy makers put a great deal of time into developing the policy, local actors are often not given a proportionate amount of time to understand the intent of the policy or to translate it into practice.

RHS teachers also lacked adequate guidance regarding the practical realities of implementing the new state mandates. They felt constant pressure to cover the mandated content. At first, they simply went faster; then they cut out inquiry learning; eventually, they began to question whether it was feasible for all students to learn science. They questioned whether the Michigan standards and testing requirements were even compatible with scientific practices of critical thinking and inquiry learning. Geier et al. (2007) report that standards-based curricula can lead to standardized achievement test gains in historically underserved urban students when the curriculum is "highly specified, developed, and aligned with professional development and administrative support" 
(p. 922). However, several years of sustained support are required before the effects of the reform can be discerned.

Despite the Michigan Merit Curriculum stating the content expectations and mandating "what" students should know and be able to do to receive high school graduation credits, it is left up to the local school boards and districts to determine "how" to implement these new graduation requirements (Michigan Department of Education, 2012a). Like the Michigan Merit Curriculum, the recently adopted Common Core Standards state the "content of intended curricula" (i.e., what is to be taught) but not the "pedagogy of curriculum" (i.e., how it is to be taught) (Porter, McMaken, Hwang, \& Yang, 2011). We fear that the problem will be repeated with the NGSS, which focuses on standards, leaving curriculum, pedagogy, and assessment to local control: "The NGSS are student performance expectationsNOT curriculum. ... Additional work will be needed to create coherent instructional programs that help students achieve these standards" (Nextgenscience.org, 2013c, p. 2). Because the standards do not define a curriculum, states and local districts are charged with the "responsibility for providing more detailed guidance to classroom teachers" (Nextgenscience.org, 2013d, p. 1). It has been deemed the responsibility of the state to align curricula, instruction, and assessment and to provide professional preparation for the science teachers who are charged with the responsibility of implementing these significant changes in science education.

Ironically, at a time when teachers are seemingly being asked to bring their professional decision making to bear on such revised and more rigorous curricula, other forces are working against them acquiring the necessary resources. For example, under the new administrative rules adopted by the state of Michigan, teachers no longer have to earn 18 credits in a graduate program to qualify for the professional teaching certificate. Instead, they only need six credit hours at an approved teacher preparation institution or the equivalent number of hours in state continuing education or district-provided professional development (or a combination thereof). At the very time national standards are becoming more specific and calling on a higher level of teacher expertise, states like Michigan are removing mechanisms that would support the development of such teacher expertise, while simultaneously passing legislation indicating that 50 percent of teacher evaluations are to be tied to student achievement scores.
Our study supports what others (Sipple, Killeen, $\&$ Monk, 2004; Spillane, 2004) have reported about the importance of the local context to the way that standards are implemented. It reiterates the findings that raising standards and requiring students to take challenging courses is necessary but not sufficient to improve learning in science (Clune \& White, 1992; Loveless, 1999; Montgomery et al., 2010; Teitelbaum, 2003). Although we do not disagree with the higher graduation standards, our study reveals that the effect of such requirements greatly depends on how they are implemented in practice at the local level. Additional resources at the school level must accompany any such policy changes; otherwise, it merely becomes an exercise in futility for the school building educators and another case of "change without difference" (Woodbury \& Gess-Newsome, 2002).

\section{Implications}

In light of these findings, our first recommendation is that science teachers-the agents who ultimately implement the reform-be brought into the reform process. Their current understanding of classroom settings could help shape policy that is more readily applicable. Teachers need to have a good understanding of the intent of the reform and need to be given time to prepare for change and to reflect upon their educational practices. Teachers must be provided with focused professional development and ongoing support from knowledgeable science educators. They need support in restructuring classes for changing schedules and more diverse student groupings, as well as professional development on how to teach detracked classes. They also need to be informed about how to implement research-based interventions that facilitate the achievement of struggling students. It is not enough for teachers to hear about it or see it modeled; they need to be coached through its implementation. Teachers require assistance in "developing the knowledge, skills, and resources to create classroom environments that promote diversity, equity, and learning, not just in science but in all content areas" (Mensah, 2013, p. 72).

Second, school- and district-level administrators need support to understand the goals of the reform; otherwise, they may adopt local policies that unwittingly confound the intent of policy. Administrators need to have an understanding of curriculum and instruction. They need to know how to gather and analyze data to evaluate the outcomes of the policies they adopt (Mandinach \& Gummer, 2013). They 
also need to rely on relevant, valid research for making decisions related to scheduling, professional development, curricula, and instruction.

Third, legislators and policy makers need to recognize that education policy is not just a set of laws or guidelines; it is social practice (Smit, 2005). Mandating rigorous standards will not automatically result in improved learning. While high standards are necessary, they are not sufficient. Legislators and policy makers must understand the local contexts and structural constraints within which policies are being implemented. They should provide specific guidance about how to achieve the mandated high standards in different contexts, especially in schools that enroll a large number of traditionally noncollege-bound students.

Finally, and most importantly, students who arrive at high school lacking the prerequisite skills for academic success need additional supports and more time for learning. This might include valuing the experiences that students bring with them, the use of culturally relevant pedagogy, and resources to support their learning (Atwater, Lance, Woodard, \& Johnson, 2013; Ladson-Billings, 1995; Lee \& Buxton, 2013). Without these coordinated and sustained efforts in science education, we will undermine the development of science skills in the next generation of students and continue to ill-prepare students for STEM-related professional fields.

\section{References}

Achieve, Inc. (2008). Aligning graduation requirements with the real world: A road map for the states. Retrieved March 12, 2011, from http://www .achieve.org/aligning-high-schoolgraduation-requirements-real-world-roadmap-states

Achieve, Inc. (2011). Closing the expectations gap. Retrieved March 12, 2011, from http://www.ecs.org/html/offsite.asp?document= http $\% 3 \mathrm{~A} \% 2 \mathrm{~F} \% 2 \mathrm{Fwww}$.achieve.org\%2Ffiles $\%$

2FAchieveClosingtheExpectationsGap2011.pdf

Achieve, Inc. (2012). Next generation science standards: Implementation. Retrieved January 11, 2013, from http://www.nextgenscience.org /implementation

Allensworth, E., Nomi, T., Montgomery, N., \& Lee, V. (2009). College preparatory curriculum for all: Consequences of ninth-grade course taking on academic outcomes in Chicago. Educational Evaluation and Policy Analysis 31, 367-392.
Atwater, M., Lance, J., Woodard, U., \& Johnson, N. (2013). Race and ethnicity: Powerful cultural forecasters of science learning and performance. Theory Into Practice, 52(1), 6-13.

Bair, D., \& Bair, M. (2011). An ethnographic policy analysis of a Michigan high school's implementation of state mandated universal college preparatory curricula. Journal of Ethnographic and Qualitative Research, 6(1), 14-31.

Bair, M., \& Bair, D. (2010). Scheduling inequality in math and science: How trimesters hurt students at risk of academic failure. American Secondary Education, 39(1), 78-94.

Buckley, J. (2012). NCES statement on PIRLS and TIMSS 2011. Retrieved January 18, 2013, from http://nces.ed.gov/whatsnew/commissioner/rem arks2012/12_11_2012.asp

Byrd, S., \& Langer, K. (2010). Mandating change: Assessing the implementation of the Michigan Merit Curriculum. Ann Arbor, MI: Gerald R. School of Public Policy. Retrieved January 18, 2013 from http://closup.umich.edu

Clune, W., \& White, P. (1992). Education reform in the trenches: Increased academic course taking in high schools with lower achieving students in states with higher graduation requirements. Educational Evaluation and Policy Analysis, 14, 2-20.

Dynarski, S., Frank, K., Jacob, B., \& Schneider, B. (2012). Impacts of the Michigan Merit Curriculum on student outcomes: Preliminary findings from the first cohort. Michigan Consortium for Educational research. Retrieved January 18, 2013, from http://michiganconsortium.org/ downloads/brief-2-impacts-of-michiganmerit-curriculum-student-outcomespreliminary-findings-from-first-cohort.pdf

Geier, R., Blumenfeld, P., Marx, R., Krajcik, J., Fishman, B., Soloway, E., \& Clay-Chambers, J. (2007). Standardized test outcomes for students engaged in inquiry-based science curricula in the context of urban reform. Journal of Research in Science Teaching, 45(8), 922-939.

Giddens, A. (1984). The constitution of society. Cambridge: Polity Press.

Glesne, C., \& Peshkin, A. (1992). Becoming qualitative researchers. White Plains, NY: Longman.

Guba, E., \& Lincoln, Y. (1989). Fourth generation evaluation. Beverly Hills, CA: Sage.

Ladson-Billings, G. (1995). Towards a theory of culturally relevant pedagogy. American Educational Research Journal, 32, 465-491. 
Lee, O., \& Buxton, C. (2013). This issue. Theory into Practice, 52(1), 1-5.

Loveless, T. (1999). Will tracking reform promote social equity? Educational Leadership, 56(7), 28-32.

Loveless, T. (2008). Tracking and detracking: High achievers in Massachusetts middle schools. Washington, DC: Thomas B. Fordham Institute.

Mandinach, E., \& Gummer, E. (2013). A systemic view of implementing data literacy in educatory preparation. Educational Researcher, 42(1), 3038.

Mensah, F. (2013). Theoretically and practically speaking, what is needed in diversity and equity in science teaching and learning? Theory into Practice, 52(1), 66-72.

Michigan Department of Education. (2012a). Michigan merit high school graduation requirements: Frequently asked questions (7/2012). Retrieved February 16, 2013, from http://www.michigan.gov/documents/mde/FAQ Entire_Document_12.07_217841_7.pdf

Michigan Department of Education. (2012b). MME Spring 2012. Retrieved Feb 16, 2013, from http://www.michigan.gov/mde/0,1607,7-14022709_35150_47474-_,00.html

Montgomery, N., Allensworth, E., \& Correa, M. (2010). Passing through science. The effect of raising graduation requirements in science on course taking and academic achievement in Chicago. Retrieved January 18, 2013, from http://ccsr.uchicago.edu/sites/default/files/publi cations/Science\%20_Report.pdf

Nextgenscience.org. (2013a). The need for new science standards. Retrieved April 26, 2013, from http://www.nextgenscience.org/overview-0

Nextgenscience.org. (2013b). The next generation science standards. Retrieved April 26, 2013 from http://www.nextgenscience.org/nextgeneration-science-standards

Nextgenscience.org. (2013c). Appendix A - Conceptual Shifts in the Next Generation Science Standards. NGSS public release II (pp. 1-5). Retrieved April 26, 2013, from http://www.nextgenscience.org/sites/ngss/files/ Appendix $\% 20$ A $\% 20 \% 20$ Conceptual $\% 20$ Shifts $\% 20$ in $\% 20$ the $\% 20 \mathrm{Next} \% 20$ Generation $\% 20$ Science $\% 20$ Standards\%20-\%20 FINAL.pdf Nextgenscience.org (2013d). Implementation. Retrieved April 26, 2013, from http://www.nextgenscience.org/implementation
Nomi, T. (2012). The unintended consequences of an algebra-for-all policy on high-skill students: Effects on instructional organization and students' academic outcomes. Educational Evaluation and Policy Analysis, 34, 489-505.

Patton, M. (1990). Qualitative evaluation and research methods (2nd ed.). Newbury Park, CA: Sage Publications.

Penuel, W., Fishman, B., Gallagher, L., Korbak, C., \& Lopez-Prado, B. (2009). Is alignment enough? Investigating the effects of state policies and professional development on science curriculum implementation. Science Education 93, 656-677.

Porter, A., McMaken, J., Hwang, J., \& Yang, R. (2011). Common core standards: The new U.S. intended curriculum. Educational Researcher, 40(3), 103-116.

Povall, S. (2006). Policy ethnography: Exploring the local processes of public policy implementation. Retrieved April 1, 2010, from http://www.liv.ac.uk/managementschool/ethnog raphy_conference/papers 2006/50_Sue_Povall_

Rose, H., \& Betts, J. (2004). The effects of high school courses on earnings. The Review of Economics and Statistics, 86(2), 497-513.

Roth, M., Tobin, K., \& Ritchie, S. (2007). Time and temporality as mediators of science learning. Science Education, 92, 115-140.

Rubin, B. (2008). Detracking in context: How local constructions of ability complicate equity. Teachers College Record, 110, 646-699.

Sipple, J., Killeen, K., \& Monk, D. (2004). Adoption and adaptation: School district responses to state imposed learning and graduation requirements. Educational Evaluation and Policy Analysis, 26, 143-168.

Smit, B. (2005). Teachers, local knowledge and policy implementation: A qualitative policy practice inquiry. Education and Urban Society, 36, 292-303.

Spillane, J. (2004). Standards deviation. Cambridge: Harvard University Press.

Strauss, A., \& Corbin, J. (199). Basics of qualitative research: Grounded theory procedures and techniques. CA: Sage Publications.

Teitelbaum, P. (2003). The influence of high school graduation requirement policies in mathematics and science on student course-taking patterns and achievement. Educational Evaluation and Policy Analysis, 25, 31-57. 
Troman, G., Jeffrey, B., \& Beach, D. (2006). Researching educational policy: Ethnographic experiences. London: Trufnell Press.

Woodbury, S., \& Gess-Newsome, J. (2002). Overcoming the paradox of change without difference: A model of change in the arena of fundamental school reform. Educational Policy, 16(5), 763-782.

IJEPL is a joint publication of PDK International, the Faculty of Education at Simon Fraser University and the College of Education and Human Development at George Mason University. By virtue of their appearance in this open access journal, articles are free to use, with proper attribution, in educational and other non-commercial settings 90 days after initial publication. Copyright for articles published in IJEPL is retained by the authors. More information is available on the IJEPL Web site: http://www.ijepl.org 